research proposals-others were offered verbally-fell into five overlapping categories: factors uniting, dividing, or integrating the labor movement at the national level or beyond (national integration, nationalism and internationalism, immigration, ethnic and racial antagonisms); the cross-cultural comparison of specific institutions, or of the interaction of such institutions (mutual benefit societies, workers' parties, trade unions, cooperatives, etc.); the influence of various groups active within or alongside the movement (cadres of diverse background, intellectuals, artists, the young, labor journalists); the relationship between labor and other social groups (farmers) or forces (religion); and political activities and ramifications of the movement. In fact, the call to reconsider the multifaceted intersection of class activities and those of the state recurred throughout the conference. Without minimizing the complex theoretical and practical problems involved, the wide-ranging discussions disclosed the potential richness and promise of systematic, comparative labor history. As John Saville put it, the discourse of the conference shifted from that of crisis to that of challenge.

The assembly did not attempt to set an agenda for research. A few groups planned to pursue specific projects, and the IISH is prepared to lend moral and possibly material support to promising proposals, some of which may be taken up in a postgraduate research program that it plans to initiate. The Institute has put labor historians doubly in its debt, first, for the appearance of the Formation volumes, which will long serve as handbooks on national labor movements, and second, for its initiatives in comparative labor history, of which the Alkmaar conference is an impressive example.

\title{
NOTES
}

1. Marcel van der Linden and Jurgen Rohajn, eds., The Formation of Labour Movements, 1870 1914: An International Perspective, 2 vols. (Leiden, 1990). Half of the forty delegates at Alkmaar, from twenty-one countries, contributed to the Formation volumes. Delegates'also received the IISH's related bibliography, Karin Hofmeester, ed., De ontwikkeling van arbeidersbewegingen in internationaal vergelijkend perspectief. En geannoteerde bibliografie (Amsterdam. 1990).

2. This report drew on a wider study of syndicalist movements conducted with Marcel van der Linden of the IISH.

\section{Labor Law in America: Historical and Critical Perspectives}

\author{
Christopher Tomlins \\ La Trobe University
}

On March 20-21, 1990, the University of Maryland Law School and The Johns Hopkins University History Department jointly hosted a conference organized to 
discuss the burgeoning history of American labor law. An audience of fifty, composed in roughly equal parts of historians, law academics, and political scientists, discussed eleven papers specially commissioned to tap the broad range of scholarship currently under way in labor law history. Chronologically wideranging, the papers represented a welcome broadening from the traditional identification of labor law with labor organization and collective bargaining. Authors employed a variety of analytic techniques, from doctrinal analysis to political and social theory. Their papers were united, however, by a common concern with the interrelationship of law and power in mutliple cross-cutting dimensions: legal and political institutions and ideologies, gender, and class. Papers were distributed in advance to facilitate discussion. Throughout, exchanges were informed, lively, and, on occasion, passionate.

The first session, on combinations and conspiracy doctrine in the nineteenth century, featured papers by Robert Steinfeld (Law School, SUNY-Buffalo) on "The Political Economy of the Early Labor Conspiracy Cases" and Victoria Hattam (Political Science, Yale University) on "Workers as Conspirators: Judicial Regulation of Labor Under the Common Law Doctrine of Criminal Conspiracy." Steinfeld's paper concentrated on the essential role of legal artifice in the construction of economic institutions. He used the Philadelphia Cordwainers' case as an illustration of the competing visions between masters and journeymen of a "free market," fought out at the level of which forms of market action were to be privileged in law. Hattam's broad analysis of nineteenth-century labor-conspiracy prosecutions invited historians to pay more attention to the mild penalties and comparative absence of protest attending pre-Civil War conspiracy prosecutions. Contrasting this situation with the far more coercive approach of the courts in the second half of the century, Hattam concluded that only then did the labor movement turn toward class-conscious protest against the conspiracy doctrine.

In the second session, Christopher Tomlins (Legal Studies, La Trobe University) spoke on "Law and Power in the Employment Relationship, 1800-1850." Tomlins's paper analyzed the power asymmetries inherent in legal descriptions of the roles of the parties in the nineteenth-century employment relationship. $\mathrm{He}$ traced these to the postrevolutionary reception of a "generic" English law of master and servant not previously established in the colonies, and he demonstrated how courts applied this body of law to the generality of hired labor during the course of the nineteenth century.

The third session brought papers from Lea VanderVelde (College of Law, University of Iowa) and Amy Dru Stanley (History, University of California, Irvine). VanderVelde's paper, "The Abolition of Slavery and the Legal Rights of Actresses who Refuse to Perform," examined the impact of abolitionist ideology on courts confronted by employer suits invoking the equitable doctrine of specific performance in personal services contracts. She found that the courts' desire in the aftermath of the Civil War to follow a substantive "free labor" principle protective of an individual employee's freedom had by the 1880 s been displaced by a 
formalistic commitment to enforcement of the letter of the contract. Stanley's paper, "The Underside of Contract Freedom: Obliging the Beggar to Labor," described the imposition of penal laws against vagrancy in the post-Civil War North. Tellingly, she stressed that the creation of market relations in no sense implied the withering away of coercive labor laws; rather, rules of contract simply masked the legal compulsions that continued to underlie free labor.

Both VanderVelde's and Stanley's papers illustrated the decidedly equivocal quality of the "free" in the nineteenth century's "free labor" ideology. A similar message was delivered in the day's final session by Karen Orren (Political Science, UCLA). In "Belated Feudalism: Labor Adjudication in the Late Nineteenth Century," Orren argued that as late as the second half of the nineteenth century the "conceptual world" of American labor law was still one with roots in the premodern English law of master and servant. Orren saw the final loosening of that stranglehold of six centuries' tradition as coming only in the struggles of the late nineteenth and early twentieth centuries.

The second day began with papers from Daniel Ernst (Law Center, Georgetown University) and William Forbath (Law School, UCLA). In "The Danbury Hatters Case, 1903-1917," Ernst offered a subtle reexamination of Loewe $v$. Lawlor. He invited his audience to view the case in the context of a confrontation between the nineteenth century's entrepreneurial capitalism and the reconstructed corporate economy of large-scale organizations-business and labor-which emerged from the depression of the 1890s. Forbath's paper, "Law and the Shaping of Labor Politics in the United States and England," offered a sweeping comparative analysis of the differential impact of legal and political institutions on American and English labor. Forbath contrasted the unique power of courts in America's institutionally fragmented federal state with the unitary sovereignty of the British parliamentary state. English unions could seek relief from a hostile judiciary through political activity intended to influence a constitutionally sovereign legislature, but American labor's political victories always subject to the judiciary's constitutional trumps.

In the penultimate session, Kenneth Casebeer's "The Workers' Unemployment Insurance Bill: American Social Wage, Labor Organization, and Legal Ideology" examined Ernest Lundeen's revolutionary alternative to the WagnerLewis social security bill. Casebeer (Law School, University of Miami) described the Workers' Bill's program of wage floors funded by redistributive taxation and administered through workers' councils, stressed its extraordinary rank-and-file popularity, and pointed out its role in the split between the AFL and the CIO. He used the story of the Workers' Bill both to criticize the structure and logic of contemporary labor law-rules facilitating the imposition of economic risk directly upon the work force - and to show, by a "near miss" analysis of the bill's chances for passage, that this structure is in no sense immutable.

The final session, on the institutional legacy bequeathed by the 1930 s and its contemporary decomposition, comprised papers by Eileen Boris (History, Howard 
University) and Joel Rogers (Sociology and Law, University of Wisconsin). In "Homework Regulation and the Devolution of the Postwar Labor Standards Regime: Beyond Dichotomy," Boris explored the regulatory dichotomy between home and workplace created by the prohibitions on industrial homework in the Fair Labor Standards Act. She showed how this regulatory and ideological dichotomy rendered the FLSA unable to contain the rightist assault on labor standards, which became particularly apparent during the 1980s. Rogers's paper, "The LaborManagement Relations Act: The Legal Constraints on Unions in the Postwar Period," addressed the institutional dynamics of labor's postwar decline. A hostile legal environment helped confine unions to sectors of the economy already organized at the end of World War II. Unions did not organize outside this "core" and concentrated instead on maintaining their postwar truce with employers. This worked until the 1970s, when recession and trade shocks brought a rapid escalation in corporate assaults on labor movement strongholds and the beginnings of the catastrophic decline that ${ }^{\star}$ has continued throughout the 1980s. Rogers concluded that the unions' particularistic pursuit of self-interest made sense, given the highly centrifugal structural dynamics of the U.S. political economy. He implied, however, that had it not been for the LMRA's legal constraints the labor movement would have behaved very differently.

The conference closed with thanks to the host institutions and to the Johns Hopkins University Press for their financial support. Revised versions of the papers will be published by the Press as an essay collection.

\title{
Ninth Annual Conference, Wisconsin Labor History Society: "Reclaiming Our Local Union's History"
}

\author{
Darryl Holter \\ Wisconsin State AFL-CIO
}

One hundred labor activists, historians, and teachers gathered at the Madison Labor Temple for the Ninth Annual Wisconsin Labor History Society Conference. The topic was "Reclaiming our Local Union's History." Jeremy Brecher, author of History From Below: How to Tell the History of Your Union or Community, discussed his work with local communities and unions in several industrial areas of Connecticut.

"Building a City, Building a Movement," a video that tells the story of the Madison Federation of Labor, was introduced by Dexter Arnold, editor of Union Labor News, the monthly newspaper of the South Central Federation of Labor. Harry Miller and Jim Danky from the State Historical Society of Wisconsin discussed the historical materials available in the Society's collections. 